\title{
Whatever happened to the soul? Some theological implications of neuroscience
}

\author{
Alison J. Gray* \\ School of Psychology, University of Birmingham, Edgbaston, Birmingham, B15 2TT, UK
}

(Received 12 October 2009; final version received 23 March 2010)

\begin{abstract}
What sets human beings apart from animals? How does "mind" fit with soul? Different historical and contemporary views of the mind/soul are considered. A clinical case is used to argue that a strong dualistic position is not compatible with neuro-scientific evidence nor with the expectation of life after death found in the Abrahamic faiths. Reductive physicalism is a widely held view, but risks devaluing human life. Midgely's "many maps" model is suggested to fit better with a faith commitment. Non-reductive physicalism states that mind/soul is an emergent property of the complexity of the brain. Suggesting that there is no separable "soul" raises ethical questions, and Singer's philosophy is given as one consequent reading of the moral standing of human beings. Holistic (weak) dualism and non-reductive physicalism are suggested as possible models of the nature of persons that fits both the scientific data and the teaching of the Abrahamic faiths. It is important for mental health professionals to be clear about their own and the service users' underlying assumptions about human nature to optimise communication and prevent misdiagnosis.
\end{abstract}

Keywords: soul; mind; Bible; theology; monism; dualism; reductionism

We can all agree that we have bodies; there is little dispute about that, but do we have souls? Most people would agree that they have a mind, but how does "mind" fit with "soul?" Our experience suggests that we are more than just bodies; that "we" are in some way "inside" our bodies. What is this part that makes me a particular person, in continuity with my past and into my future? Our thoughts, feelings, memories and choices are not directly accessible to other people, which have led some philosophers to argue that these things are not really "real," but just epiphenomena, side effects of what the brain does. What is the "ghost in the machine" the part that is me and remains me over time, when all the cells in my body have changed?

Human beings are animals, but there is something special about us. Like other animals we have the capacity for sensation and locomotion, and care for our young. However, there are many capacities that are not found in animals, for example, philosophy and complex mathematics. The ancients recognised something that sets humans apart, and called this the "soul," what makes us unique individuals, the seat of the will and personality, the part that is capable of communication with transcendent reality.

*Email: GrayA@bham.ac.uk 
The Latin word for "soul" (animus) is also translated "mind," the two concepts of soul and mind overlap to a very large degree; mind is the non-spiritual, more scientific equivalent of soul. A major problem with speaking about the soul/mind is that by using a noun we reify the concept and talk as if it had an actual structure and measurable form, and as if soul/mind were somehow separable from the body.

Soul, historically, has been used in a substantive sense, all persons have a soul, however, it can also be used in a qualitative sense (Ward, 1998). We all have a soul, but some have a more developed and refined soul than others, spiritual disciplines help us to allow God to develop our souls, and hence become better people, making better choices and stronger at resisting temptation.

Mind is a much more precisely developed and scientific concept and includes functions such as memory, perception, emotions and decision making. As we will see later these faculties would fit into St Thomas Aquinas model of the functions of the soul.

It is no longer acceptable to speak of soul in the scientific world, the term is simply not used except to add spice to the title of popular neuroscience books (e.g. Churchland, 1995; Crick, 1994; Hofstader \& Dennett, 2001). Even speaking of spirit is controversial (Cox \& Gray, 2009).

The 1990s were the American "decade of the brain" which saw a focus of work on the brain, and the mind (Sorabji, 1999). There have been massive leaps forward in imaging of the brain since the first CAT scans in the 1970s and we can now look at the brain's activity whilst someone is thinking, meditating or praying. However, the data from such experiments are limited. We can investigate the activity of the brain in great detail, but we can only know what is going on in someone's mind indirectly, by his or her speech and actions. How brains generate conscious awareness is a challenge to the neurosciences; we have explained how every other bodily organ works, but consciousness is a last remaining mystery.

\section{Different views of the soul}

Dualism is the most common concept of soul in Western societies. The soul is made of different stuff, separate from the body. The Greek philosopher Plato (c427-348 BC) believed that souls were pre-existent, immortal, spiritual substances trapped inside bodies. Many Christians hold a Platonist view, seeing the soul escaping at death to be with God. However, (most of) the Bible suggests that the soul is not an extra separate bit, but that we human beings are ensouled bodies. In the Bible "person" refers to a living, breathing holistic entity; this view is called monism (Murphy, 1998).

The final major option, physicalism, is held by many, particularly atheistic scientists. Here the soul is an unnecessary concept; all of the properties of the soul can now be explained by neurosciences and genetics and therefore there is no soul (Hofstader \& Dennett, 2001). In this view we are nothing but atoms and molecules, physical bodies and no more.

\section{Case history}

In 2004, a 40-year-old schoolteacher was arrested in America and charged with paedophilia. He had made a sexual approach to his stepdaughter (Burns \& Swerdlow, 2003). When he was investigated, a large amount of child pornography was found on his computer and his wife discovered he had been using prostitutes. The teacher was thrown 
out of the house and put through a 12-step program for sex addicts. He failed this, since he continuously tried to chat up the other members of the program looking for sex. Throughout the teacher knew that his behaviour was unacceptable and made efforts to hide his actions; when challenged he said that the pleasure principle outweighed other considerations.

On the day before he was due to be sent to prison the teacher attended the local hospital complaining of unsteadiness and the drive to rape his landlady. He did not want to force her sexually, but feared he might.

Along with the headaches there were some subtle neurological signs. A scan showed a large orbitofrontal brain tumour. Once the tumour had been cut out and treated his excessive sexual drives went away. After a while, with psychological treatment he was able to return to his wife and stepdaughter.

Two years later he started collecting pornography again. He was rescanned and the tumour was found to have re-grown. Again when the tumour was cut out he became able to control his drives again.

Here we have a man whose self-control and personal morality was undermined by a brain tumour. Physical damage to his brain caused a change in his interests, drives and actions. One question is whether this is a new drive to underage sex, or whether the impulse was always there but would have remained controlled had the tumour not affected the inhibition centres. The teacher retained awareness that society would frown on his actions and attempted to conceal his behaviour, and in the end he resisted his impulses to assault his landlady. His self-control was reduced, but not totally removed.

Without a brain scan the tumour would not have been identified and the man would have been seen simply as sinful. The tumour seems to have had a major impact on his selfhood, his soul. If the soul were an immaterial thing totally separate from the body how could the brain tumour affect it? How can changes in the brain affect the spiritual life? How can the virtues of faithfulness and self-control just disappear?

Human beings interact with the world through their brains. All conscious sensory input comes in through the brain, all conscious motor output starts in the brain. Consciousness is a great mystery, but clearly has to do with the brain. Susan Greenfield suggests that there is no magic bullet, no single point where consciousness $i s$, instead it is a qualitative issue (Greenfield, 1999). The number and placement of neurones firing at any moment will determine your conscious experience. Further she suggests that there are degrees of consciousness, such that a small child has a lower degree of consciousness than an adult, an animal a lower level than this. This seems to be the best current neurophysiological explanation of consciousness, but it does not explain how we experience the colour yellow as yellow, let alone how humankind interacts with the transcendent.

\section{Ancient views of the soul}

What can the Hebrew bible tell us about the soul?

In reviewing the biblical teaching on soul/mind, we must recognise the limits of a wordbased approach. We simply do not know precisely what the ancients meant by their words which we translate as soul, spirit, etc. We tend to read back later concepts onto the earlier documents, which is generally not justified.

The biblical authors do not directly address the question of human nature and how heart, mind, spirit and soul interact. The Hebrew bible speaks of people as whole human beings, one integrated reality, not made up of separable parts. We do not have a soul 
we are a soul. Humans are a body, made of dust, which is brought to life by God's breath (Gen 2:7) (Freedman, 1992). Ensouled bodies are only seen to be dead when breathing has ceased, hence modern Orthodox Jewish Rabbi's do not accept the concept of brain death (Rosner, Bleich, \& Brayer, 2000). Humans are made in the image of God (Gen 1: 26-27). The image of God has been taken to mean different things from physical characteristics to the ability to know and be responsive to other people and to God (Green, 1998).

The ancient Israelites generally expected to live on through their dependents there are few references to immortality in the Hebrew bible.

In New Testament times the Pharisees looked forward to resurrection, but the Sadducees denied the possibility. There is a range of views on the nature or existence of the soul influenced by the Hellenistic culture alongside which the Jews lived.

The gospels speak often of resurrection and eternal life. In order to make sense of this teaching and of the resurrection of Jesus, the early Christians had to consider in what way a person could live on even though they die. The Greek concept of immortal souls gave one possible answer to this puzzle.

\section{Philosophical history of the concept of soul/mind}

Plato (c.427 - 348 BCE) saw a person as an immortal soul trapped inside a mortal body.

The soul is the essence of the person, and decides what they do. In Plato's view the soul has three parts; at the base - "appetites," then "spirit" (as in a spirited horse) and then "reason." Reason governs over appetites by means of the spirit.

Aristotle (384-322 BCE), Plato's student, wrote a major treatise on the soul "De Anima." Aristotle argues that although we cannot examine or investigate the soul directly, we can come to know the nature of something by looking at its properties and results. He saw the person as consisting of a body, with a soul, a life principle which gives them their powers and attributes.

Aristotle's philosophy is called hylomorphism from the Greek hylo "matter," and morphe "form"; all substances are seen as forms inhering in matter. The term "matter" is broader than the English word; the "matter of X" means "that out of which X is made" not just physical substances. Letters are the matter of syllables, clay is the matter of bricks, and bricks are the matter of a house (Shields, 2008). The soul is the form of the body, which is the "cause and first principle of the living body" (Aristotle, 1993). The soul is "that which makes living things alive" (Aristotle, 1993). The soul cannot function when separated from the body; a body without a soul is more like a statue than a living person. The body and soul are intimately connected and need each other for full function.

If then we are to speak of something common to every soul, it will be the first actuality of a natural body which has organs. Hence too we should not ask whether the soul and body are one, any more than whether the wax and the impression are one, or in general whether the matter of each thing and that of which it is the matter are one. (Aristotle, 1993)

In his later writings, Aristotle taught that the soul is a function of the body and dies with the body. Plants and animals have "nutritive" and "sensitive" souls; humans in addition have a "rational" or "intellectual" soul. Aristotle is generally interpreted as seeing the soul as something like a life-energy, a different aspect of the person, rather than a totally separate spiritual object with its own independent existence. Scholars argue about whether Aristotle's views are a form of monistic materialism, or weak dualism, or perhaps something else (Shields, 2008). 
Early Christian writers generally seem to hold a dualist view of souls and bodies, although there were disputes about the precise nature of the soul. For example, Tertullian (160-220 AD) taught that the soul was physical, and generated from the parents' souls with the body at conception (New Advent Catholic Encyclopaedia, n.d.). Origen (185-224) followed Plato, for him the soul was eternal, incorporeal and pre-existing the body; he was declared a heretic in 553 for the views attributed to him by his followers, including that on the pre-existence of souls (New Advent Catholic Encyclopaedia, n.d.). Augustine (354-430) taught a platonic view; a human being has an immortal soul temporarily using a human body. The soul is tripartite, Will rules over Intellect and Passions.

This emphasis on the soul and the need to cultivate the soul's higher faculties and repress the body has had a strong influence on Christian spirituality leading to a marked dualism.

Thomas Aquinas (1225-1274) developed his views by considering what human persons do, what powers must be operating, and hence what the soul must be like. He reviewed all that was available to him particularly writings that had been rediscovered by Christendom following the crusades including Islamic scholars, and Aristotle. (Aquinas, 1265).

Aquinas saw the soul as incorporeal and immortal, which would be re-clothed in a body at the resurrection. He distinguished vegetative faculties (shared with plants and animals) then sensitive faculties (shared with animals) including internal and external sensation, and appetites. Over these were rational faculties, which are distinctively human, consisting of passive and active intellect and will. The will is an appetite for goodness, and hence motivates us towards God. The soul needs a body, a soul can exist on its own, but for full function a soul needs to be embodied. Resurrection and re-embodiment is essential for the afterlife (Ward, 1998). This view seems to be a form of holistic dualism, a soul can exist on its own but its normal and preferred state is to be embodied.

Rene Descartes (1596-1650) developed a mechanical explanation for all of nature except the human mind. His dualistic thought was very important in the development of modern science. He concluded that body and soul were two separate and different things; body, which works like a machine and is extended in space and soul or mind, which is a non-material entity, in the pineal gland, and lacks extension in space. Descartes viewed animals and plants as soft-tissue machines, with no element of rationality and taught that since animals have no minds they cannot feel pain in a meaningful sense.

Cartesian dualism in its strongest form, leads to a major philosophical puzzle - the mind-body problem. How can a totally separate non-material mind influence a physical body? Mental activity happens, physical activity happens, but there is no clear mechanism for the two to interact.

Ryle has suggested that this puzzle is due to a category error. There is no polar opposition between mind and body, a cause can simultaneously be both physical and mental (Ryle 1949).

\section{Modern views of the soul}

\section{Physicalism/materialism}

Many scientists and neo-Darwinians would argue that there is no such thing as soul, for example, the philosopher Daniel Dennet holds that the soul is an unnecessary concept, 
all of the properties of the soul can now be explained in purely physical terms by neurosciences and genetics and so there is no soul (Hofstader \& Dennet, 2001).

Nobel prize winner Frances Crick writes

that you, your joys and your sorrows, your memories and your ambitions, your sense of personal identity and free will, are in fact no more than the behavior of a vast assembly of nerve cells and their associated molecules. (Crick, 1994)

This is reductive physicalism, the idea that everything can and should be explained in the simplest possible physical terms; it insists that there could be a complete explanation of a human being in terms of the atoms and molecules in their bodies. All moral, emotional and religious experiences will be explained eventually by the physical sciences, and thereby rendered meaningless and valueless.

Reductionism is fundamental to what scientists do, looking for the simplest possible explanation and not postulating complex structures or occurrences unnecessarily. We can view all human ways of knowing as an inverted pyramid with sub atomic particles at the base rising through the individual body, to ways of looking at communities, with ways of looking at the world as a whole at the top. See Figure 1. These different levels of structures link to different levels of analysis from quantum physics at the base through chemistry and biology up to sociology and international politics.

Scientists look at things at the simplest possible level, moving down the pyramid. This attitude has been extremely successful and has led to the scientific revolution and modern technology. Reductionism is taken to an extreme by suggesting that humans are nothing but our bodies, nothing but a pile of chemicals, nothing but molecules and atoms. This is as blinkered as analysing a beautiful painting in solely terms of the chemical composition of the pigments, without standing back to observe the meaning of the whole composition.

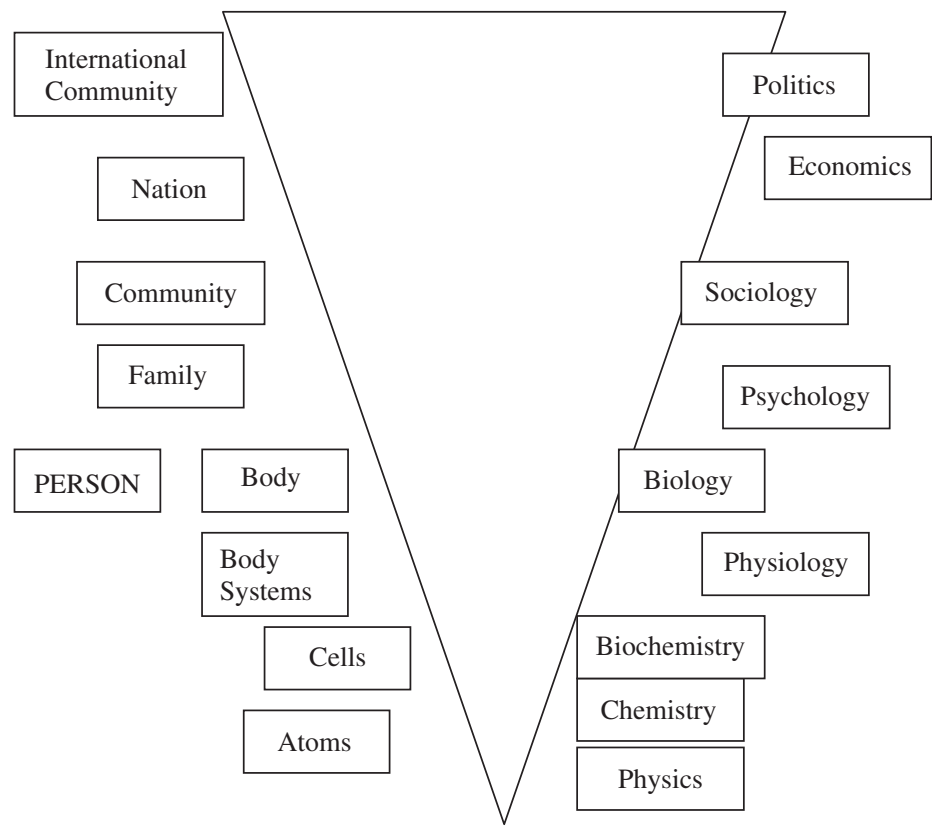

Figure 1. The different levels of analysis and corresponding academic disciplines. 
Reductionism ignores the usefulness of different levels of analysis. It may be true that John moved his arm because the signal came down his neurones and these particular muscles contracted and so forth. It may be equally true, and rather more significant, to say John moved his arm to stop his beloved daughter running into the road.

Reductionism potentially devalues life, leading to people having no more significance than the chemicals of which they are made, and opens the door to treating people as objects, and hence to easy abortion, euthanasia and on to many crimes and atrocities.

One alternative to reductionism, which fits better with a faith commitment, is the many maps model developed by Mary Midgley (Midgely, 2000). In an atlas there are many different maps, one showing vegetation, another rainfall, one showing political boundaries, another elevation above sea level. There are many maps but only one world. The different maps are equally valid, and useful for different purposes. Midgley describes scientific enquiry as like looking into

a huge aquarium. We cannot see it as a whole from above, so we peer in at it through a number of small windows... We can eventually make quite a lot of sense of this habitat if we patiently put together the data from different angles. But if we insist that our own window is the only one worth looking through, we shall not get very far (Midgley, 2003).

\section{Anatta: no self}

Buddhism denies the existence of a soul, and denies the reality of the material world. There is no permanent, enduring "self" behind experience, simply a collection of parts bound together. Attachment and desire are overcome by following the eightfold path of the Buddha over many lifetimes. Liberation consists of the breaking of these bonds of attachment and desire and the dissolution of the self into the ultimate, or reaching higher consciousness "such that no sense of individual self, the alleged soul possessor and solitary enjoyer of experiences, remains” (Ward, 2008).

\section{Pluralism}

Pluralism (in philosophy) is the suggestion that there are many different substances making up reality; physical, spiritual and other forms. These "other forms" could include, for example, a world of objective knowledge such as "theoretical knowledge coded on material substrates and cultural heritage." (Popper \& Eccles, 2003). Certain Christian bible passages seem to suggest that humankind is made up of three substances "body, soul and spirit" (1 Thess 5:23, Heb 4: 12) this is more often taken to be an inclusive term to mean our whole being inside and out (Douglas \& Comfort, 1990).

\section{Dualism}

The idea that the soul is a separate bit which is put into a physical body at conception, quickening or at birth is very ancient. The Greek philosopher Plato believed that souls were pre-existent, immortal, spiritual substances trapped inside bodies. Many Christians hold a Platonist view, seeing the body as a shell and the soul escaping at death to be with God. This is radical or "strong" dualism, mind and body are utterly independent, which leads to mind-body problems of how they interact. Many branches of Hinduism teach strong dualism; the soul passes from one embodied life to another seeking to overcome its attachments and aversions and become pure consciousness (Ward, 2008). A similar view is found in many new age teachings. 
Science fiction often presents a strong dualistic view of humanity, for example, in the classic tropes of swapping of minds into different bodies, or uploading a mind into a computer. ${ }^{1}$ Zombies are bodies without souls or minds, a collection of atavistic hungers without morality. Vampires deny that they have souls, but clearly have minds - desiring, thinking, planning and acting. Trans-humanists believe in improving human beings through technology, and expect that it will someday be possible for humans to be immortal by mind upload (humanityplus, 2009).

The case of the teacher described above is not compatible with a strong dualist position, clearly the body had a direct effect on the mind; the teacher's brain states and behaviour were directly influenced by the tumour. There must be another way of viewing soul which accommodates this and similar clinical material without denying the possibility of eternal life. The two main options currently are a form of weak dualism, and nonreductive physicalism.

Weak dualism or holistic dualism, describes the belief that mind and body are different, but interact (Watts, 2002). The person is made up of separable parts, but the person is the whole functioning together (Van Staden, 2006).

We are not forced to choose between mind and body. The unit is the whole person (Midgely, 2000).

Keith Ward identifies mind and body as subject and object. The mind requires the body to exist, but is not simply part of the body. Mind and body are two poles of the same reality. Mind, the subjective knows what it is like to be the person; body is the appearance of the person to others (primarily to God) (Ward, 2005).

\section{Monism}

Animistic religions are generally monistic, seeing all of reality as being of one substance. They extend the concept of soul not just to plants and animals, but to trees, rocks and mountains. This pantheism leads to a great respect and care for the creation, and has influenced Christian theology in the development of Panentheism-the view that the universe is contained within God (McFague, 1993).

As we saw above the authors of the Hebrew bible seem to assume that a person is a single integrated whole, an embodied soul.

Some Christian neuroscientists and philosophers have described non-reductive physicalism, a form of monism which takes into account the biblical revelation and recent scientific discoveries (Brown, Murphy, \& Maloney, 1998; Graves, 2008). "The person is a physical organism whose complex functioning, both in society and in relation to God, gives rise to 'higher' human capacities such as morality and spirituality" (Brown et al., 1998).

In this view the physical is all there is, Soul/mind is an emergent property of the complex structures of the brain.

Emergence means that as systems become more complex unexpected properties often emerge which cannot be predicted from the smaller parts. Weather systems are a classic example, as are swarming patterns of animals. The whole is much more complex than the parts (Corning, 2002). Mind is seen as an emergent property of the brain, depending on a certain level of structural complexity.

Many philosophers directly reject the concept of non-reductive physicalism as incoherent. They argue that if you are committed to physicalism the only options are 
reductionism, or eliminativism (Churchland \& Campbell, 2009); either the psychological is fully reducible to the physical, or the psychological states do not really exist (Kim 1989).

There are two main concerns with a non-separable weak dualistic, or a monistic form of soul. First (for many religious believers), there is the problem of eschatology; if there is no soul separate to the body what part of me goes to heaven? Second (for all) the ethical problem - if there is no immortal soul why can't we treat people as objects; what makes people special and worthy of especial care and attention? If mind depends on a certain level of brain structural complexity what about those whose brains are damaged or malformed?

\section{Resurrection, Heaven and the immortal soul}

If we reject dualism and a separate soul there is an apparent problem around the afterlife. Traditionally, Christians have spoken of death in dualistic ways, the body is left behind, and the soul goes on to heaven and continues to exist in God's presence.

Overall the picture from the Bible is clear that we will be resurrected in physical form at the last day, but what happens during the intervening time is not elucidated. This could support either a monistic or a weak dualistic view of the nature of the soul.

\section{Ethics and the immortal soul}

One of the arguments around abortion is the question of when the foetus becomes a person. The standard religious answer is when God imparts their soul. However, biologically there is no clear point when ensoulment happens. There is a continuous development from the moment of fertilisation to birth and after. The traditional Muslim and Roman Catholic positions are that the soul is present from the moment of conception. This leads to a ban on embryo research and assisted reproduction, (since this entails the creation of surplus embryos, only the best of which are placed in the womb). Communication between mother and foetus starts around five days after fertilisation, when the ball of cells implants into the lining of the womb. To the end of week one there is the possibility of the ball of cells splitting into twins, which provides a philosophical quandary - if the egg has a soul at the moment of fertilisation, when do identical twins get two souls? Many eggs are fertilised but never implant, are they all persons?

The nervous system begins to be formed around 17 days, and by seven weeks the embryo looks human. Movement is usually first felt by the mother around week 20 (quickening) although the embryo has been moving undetectably before this. St. Thomas Aquinas held that the foetus has a vegetative, then an animal soul which dissolves and is replaced by a human soul around the time of quickening (Aquinas, 2006).

If there is no separate soul when does the ball of cells become a person worthy of care and respect?

An extreme view is that exemplified by Professor Peter Singer, an Australian atheistic philosopher. He denies the possibility of "soul," and uses "personhood" to discuss the territory. Singer argues that a person is a being that is aware of self and the future, of having wants and desires. This self and future awareness does not develop for months after birth, and may be lost before death, and hence Singer argues

killing a newborn baby is never equivalent to killing a person, that is, a being who wants to go on living (Singer, 2009). 
The baby only has worth if a person cares about them; they have no intrinsic value. At the end of life people with brain injuries or dementia may have no sense of the future; hence they can be killed providing that that is what they would have wanted before they lost capacity to choose (Singer, 1993).

Some have seen this as diminishing the standing of human beings, but Singer would argue that he is trying instead to increase our respect for animals (Singer, 1993). Non-human primates who have learned basic communication skills, (e.g. sign language), and seem to plan for the future are then to be counted as persons. Personhood would then be granted to other animals which are intelligent, demonstrate memory and planning and have complex social groups, for example, dolphins and elephants (Francion, 2008).

This philosophy has risks to the care and lives of infants and those with damaged brains. Singer (Singer, 1993) states that if the parents of a multiply disabled child wish that child to remain alive then the state should provide all support for that child. However, there is a slippery slope here; anecdotally, there is much evidence of pressure on pregnant women to terminate a Downs syndrome foetus, one would expect that legalising infanticide would lead to similar pressures. If a baby could be killed because of their disability there will be subtle, social pressure on families to take that route and save the time, trouble and expense of raising a disabled person.

The same argument applies towards the end of a person's life, those with dementia can no longer contribute to the economy, and they are a drain on resources, if they have no intrinsic value why should they not accept euthanasia?

We are challenged by this philosophy to recognise the many continuities of humankind with other animals and to treat animals with respect and care (Oppenheimer, 2006).

Without a spiritual framework the value of human beings is reduced to the value which society puts onto them, the dignity of humankind then comes from social structures and laws. Ultimately, people are of value "because we say so" and that is a very weak position. Society can decide not to value certain people, to label them as non-persons, as happened in Nazi Germany leading to the holocaust, and to the many people "disappeared" by governments all round the world.

\section{Conclusion}

It is important for mental health professionals to recognise their own underlying assumptions about the nature of humankind, as well as that of their patients and service users. Clarity about our different beliefs and values will help enable clear communication, accurate diagnosis and effective treatment. For example, belief in ancestral spirits, or active ghosts may be entirely coherent, rational and logical given a strongly dualistic view of personhood, and not a sign of illness.

Evidence from the neurosciences and clinical cases has demonstrated that personality and mental events depend on the brain. Strong dualism cannot account for the clinical data; there is some interaction between mind and brain. Imaging studies have shown that mental events can be correlated with brain events, but it is a large step from there to saying that the mental event is nothing but the brain event. Weak dualism or non-reductive physicalism can fit with both the scientific data, and with the biblical testimony on the nature of humankind and the hope of an afterlife. We are more than just our bodies; we are whole people with an embodied spiritual nature, embedded in our relationships, our society, history and culture. 


\section{Note}

1. Recent examples include the film Scooby Doo 2, and BBC radio programme "Doctor Who the Eighth doctor series" 1:3 (Immortal beloved [Aired 18.9.09])

\section{References}

Aquinas, T. (1274). Summa Theologiae [Adobe Digital Editions version]. Retrieved September 4, 2009, from http://www.ccel.org/ccel/aquinas/summa.html

Aquinas, T. (2006). The world order (M.J. Charlesworth, Trans.). Cambridge: Cambridge University Press.

Aristotle. (1993). De anima (D.W. Hamlyn \& J. Shields, Trans.). Oxford: Oxford University Press. Brown, W.S., Murphy, N., \& Malony, H.N. (Eds). (1998). Whatever happened to the soul? Scientific and theological portraits of human nature. Minneapolis, MN: Augsburg Fortress.

Burns, J.M., \& Swerdlow, R.H. (2003). Right orbitofrontal tumor with pedophilia symptom and constructional apraxia sign. Archives of Neurology, 60, 437-440.

Churchland, P.M. (1995). The engine of reason, the seat of the soul: A philosophical journey into the Brain. Cambridge, MA: MIT Press.

Churchland, P.S., \& Campbell, G. (2009, March 13). 'On neurophilosophy' [Audio Podcast]. Retrieved September 5, 2009, from http://docartemis.com/brainsciencepodcast/2009/03/podcast55-churchland

Corning, P.A. (2002). The re-emergence of "emergence": A venerable concept in search of a theory. Complexity, 7(6), 18-30.

Cox, J., \& Gray, A. (2009). Psychiatry for the person. Current Opinion in Psychiatry, 22, 587-593.

Crick, F.H. (1994). The astonishing hypothesis: The scientific search for the soul. London: Simon and Shuster.

Douglas, J., \& Comfort, P. (1990). New commentary on the whole Bible: New Testament. London: Tyndale House.

Francion, G.L. (2008). Animals as persons: Essays on the abolition of animal exploitation. New York: Columbia University Press.

Freedman, D.N. (Ed.). (1992). The anchor Bible dictionary. New York: Doubleday.

Graves, M. (2008). Mind, brain and the elusive soul: Human systems of cognitive science and religion. Aldershot, UK: Ashgate.

Green, J.B. (1998). Bodies - that is human lives: A re-examination of human nature in the Bible. In W.S. Brown, N. Murphy, \& H.N. Malony (Eds.), Whatever happened to the soul? Scientific and theological portraits of human nature (pp. 149-174). Minneapolis, MN: Augsburg Fortress.

Greenfield, S. (1999). Soul, brain and mind. In J. Crabbe (Ed.), From soul to self (pp. 108-125). London: Routledge.

Hofstader, D., \& Dennett, D. (2001). The mind's I: Fantasies and reflections on self and soul (pp. 3147). London: Basic Books.

humanityplus (2009). Philosophy. Retrieved September 3, 2009, from http://humanityplus.org/learn Kim, J. (1989).The myth of non-reductive materialism'. Journal American Philosophical Association, 63(3). Retrieved September 9, 2009, from http://www.jstor.org./stable/3130081

McFague, S. (1993). The body of God: An ecological theology. Minneapolis, MN: Augsburg Fortress.

Midgely, M. (2000). Consciousness, fatalism and science. In N.H. Gregersen, W.B. Drees, \& U. Gorman (Eds.), The human person in science and theology (pp. 21-40). Edinburgh, UK: T\&T Clark.

Midgley, M. (2003). The myths we live by. London: Routledge.

Murphy, N. (1998). Human nature: Historical, scientific, and religious issues. In W.S. Brown, N. Murphy, \& H.N. Malony (Eds.), Whatever happened to the soul? Scientific and theological portraits of human nature (pp. 1-30). Minneapolis, MN: Augsburg Fortress.

New Advent Catholic Encyclopaedia. (n.d). Retrieved from http://www.newadvent.org/cathen.

Oppenheimer, H. (2006). What a piece of work: On being human. Exeter, UK: Imprint Academic. 
Popper, K., \& Eccles, J. (2003). The self and its brain: An argument for interactionism. London: Routledge.

Rosner, F., Bleich, D., \& Brayer, M. (2000). Jewish bioethics. Jersey City, NJ: KTAV.

Ryle, G. (1949). The concept of mind. Chicago, IL: University of Chicago Press.

Shields, C. (1993). Some recent approaches to Aristotle's De Anima. In Aristotle (Ed.), De anima:

Books II and III with passages from Book 1 (D.W. Hamlyn \& J. Shields, Trans.) [Google Books version] Retrieved from http://books.google.co.uk/books?id=J65nNxyoKVQC\&dq=hamlyn+ $\mathrm{dw}+\mathrm{de}+$ anima\&printsec $=$ frontcover\&source $=\mathrm{bl} \&$ ots $=\mathrm{yCySfw} Y H P R \& s i g=a 61 \mathrm{AfQXjAblBd} 6$ wWaGzOKPJ5p

Shields, C. (2008). Aristotle's psychology. The Stanford encyclopedia of philosophy. In E.N. Zalta (Ed.), Retrieved from http://plato.stanford.edu/archives/win2008/entries/aristotle-psychology/

Singer, P. (1993). Practical ethics (2nd ed.). Cambridge: Cambridge University Press.

Singer, P. (2009). Frequently asked questions. Retrieved from http://www.princeton.edu/ psinger/ faq.html

Sorabji, R. (1999). Soul and self in ancient philosophy. In J. Crabbe (Ed.), From soul to self. (pp. 8-32). London: Routledge.

Van Staden, C.W. (2006). Mind, brain and person: Reviewing psychiatry's constituency. South African Psychiatry Review, 9, 93-96.

Ward, K. (1998). In defence of the soul. Oxford: One World.

Ward, K. (2005). Science and the human person. Retrieved from http://www.gresham.ac.uk/ event.asp?PageId $=45 \&$ Event $I d=272$

Ward, K. (2008). The big questions in science and religion. West Conshohocken, PA: Templeton Foundation Press.

Watts, F. (2002). Theology and psychology. London: Ashgate. 